\title{
Ethnobotanical Studies of Medicinal Plants (3) of Gilgit District and Surrounding Areas
}

\author{
R.A.Qureshi, M.A. Ghufran, K.N. Sultana, \\ M. Ashraf and A.G. Khan
}

\section{Research}

\begin{abstract}
The Gilgit District and surrounding areas of northern Pakistan are rich in plant and cultural diversity, yet have been poorly studied ethnobotanically. Surveys were conducted to identify medicinal plants being used and their uses. Distribution of knowledge about medicinal plants between men and women and two age classes was examined in order to see who holds knowledge and if knowledge is being retained or lost. Older men and women were found to know more about medicinal plants. 27 species were reported to be used for a range of purposes. The researchers conclude that there is need for development of conservation strategies in the area that will take into account local needs, perspectives and economic development opportunities.
\end{abstract}

\section{Introduction}

The northern areas of Pakistan, between $71^{\circ}$ and $75^{\circ}$ east longitude and $32^{\circ}$ and $37^{\circ}$ north latitude, stretch over an area of 28,000 square miles (Rasool 1998). According to the 1981 census the area supports a population of 573 thousand people with a density of almost 22 people per square mile. People primarily work in agriculture with this being mainly pastoralism in the areas located at higher altitudes.

The northern mountains of Pakistan are well known for their biodiversity as they are situated at the junction of three great Mountain ranges i.e., Karakorum, Himalaya and Hindu Kush (Shinwari et al.2000b). About 3000 species of plants have been reported from the area, out of which at least 124 have medicinal value (UNDP/IUCN, 1999). Whereas, these three mountain ranges collectively contain about 25,000 species (about $10 \%$ of world plant species), out of which around 10,000 are economically or medicinally useful (Pei 1992).
The people of the Himalaya area possess a wide range of cultures, dialects and traditions. People living in the mountains of Pakistan use plants in many ways including medicines, timber wood, firewood, food, and fodder. (Hussain \& Khaliq 1996). People are dependent upon their surrounding environment for all of their needs. Cutting firewood, timber for construction and other utilities has imposed a serious threat to valuable plant species found in the region as forests have been reduced. Excessive use of local resources results in threats of flooding, mud flows and landslides. Heavy economic losses occur from flooding and landslides almost every year. One such devastating flood recently hit the entire area in June through July of 2005. As is seen around the world, as human populations grow, there is a great impact of human activities on vegetation as well as on the quality of human life (Delcourt et al. 1986).

The medicinal plants of Himalaya are habitat specific (Dhar et al. 2000) and their distribution is scattered and restricted to small areas. During the last few years, the habitats of medicinal plants all across the Himalaya have been under pressure due to urbanization and exploitation

\section{Correspondence}

R.A.Qureshi \& M.A. Ghufran, Department of Plant Sciences, Quaid-i-Azam University, Islamabad, PAKISTAN.

K.N. Sultana, Department of Plant Pathology, University of Arid Agriculture, Rawalpindi, PAKISTAN.

M. Ashraf Government Inter College, Kel, Muzaffarabad, PAKISTAN.

A.G. Khan, Department of Microbiology, Quaid-i-Azam University, Islamabad, PAKISTAN.

lasara37@hotmail.com

Ethnobotany Research \& Applications 5:115-122 (2006) 
of raw materials by pharmaceutical companies (Tandon 1996). In order to develop strategies for the conservation of medicinal plants, it is necessary to collect traditional knowledge of the plants, their distributions, and any traditional conservation practices.

Herbal medicine even today plays an important role in rural areas and various locally produced drugs are still being used as household remedies for different ailments (Qureshi \& Ghufran 2005). Some of these medicinal plants are aromatic with this likely relating to their specific value and uses. The largest family in the area is Asteraceae (Stewart 1972) which is well known for its aromatic qualities. Shinwari \& Gilani (2003) surveyed the Astore area of Gilgit to provide information on the conservation of plant biodiversity, potential income to local people, and to determine and monitor harvest levels of medicinal plants. They mentioned that rapid decline of plant resources due to their conventional use needs training of the community regarding collection of medicinal plants and their marketing.

The indigenous communities of the region have learned to use the bio-resources around them for the treatment of diseases. They depend upon the bio-resources for their primary health care because they perceive that the traditional medicines have no or lesser side affects (Kamboj 2000). Although studies of medicinal plant use by Himalaya tribes have been conducted (e.g., Bisht et al. 2006, Hussain \& Khaliq 1996), few ethnobotanical studies of medicinal plants of Gilgit district and its surrounding areas have been completed (e.g., Kazmi \& Siddiqui 1953). In view of this, the present study was conducted to identifying the medicinal plants of this district and their utilization for primary health care treatments of common ailments.

\section{Study Area and Methods}

Our study areas included localities from Gilgit and some parts of District Astore (Figure 1). Most of the people in these areas depend on agriculture, agroforestry and mountain resources. The study was conducted from March to September, 2004. Figure 1 illustrates the localities listed below from where plants were collected during the field trips:

1. Gilgit: Shaheed-i-Millat Road, Chinar Bagh, Rive road, Jinnah, Haidri Muhalla.

2. Kargah Nallah: village near Stuppa of Buddha, Power Houses, Kargah Top (Village)

3. Astore: Jaglot road side settlements, Doyan, Gorikot, Astore to Jaglot villages.

4. Hunza: Gilgit to Hunza road side settlements, Rakaposhi View Point, Minapin, Aliabad, Karimabad, Nasirabad.

5. Nomal: Valley main village and surrounding areas.

6. Naltar: Nomal to Naltar road side settlements, Naltar Valley, lakes and surrounding.

From the above locations 59 men, 36 women and 21 young boys were interviewed individually. Informants were ethnically Shein (Shina speaking), Brush (Brushaski Speaking), and Wakhi. Information on age (divided into two classes of older and younger than 50 years), gender, medicinal plants and their uses was gathered from each informant using a structured and open-ended questionnaire with the following questions:

1. Do you know the medicinal plants in your local area?

2. If yes, please name them.

3. What is the use of these medicinal plants (for which ailment)?

4. How do you use them (as a spice or a medicine)?

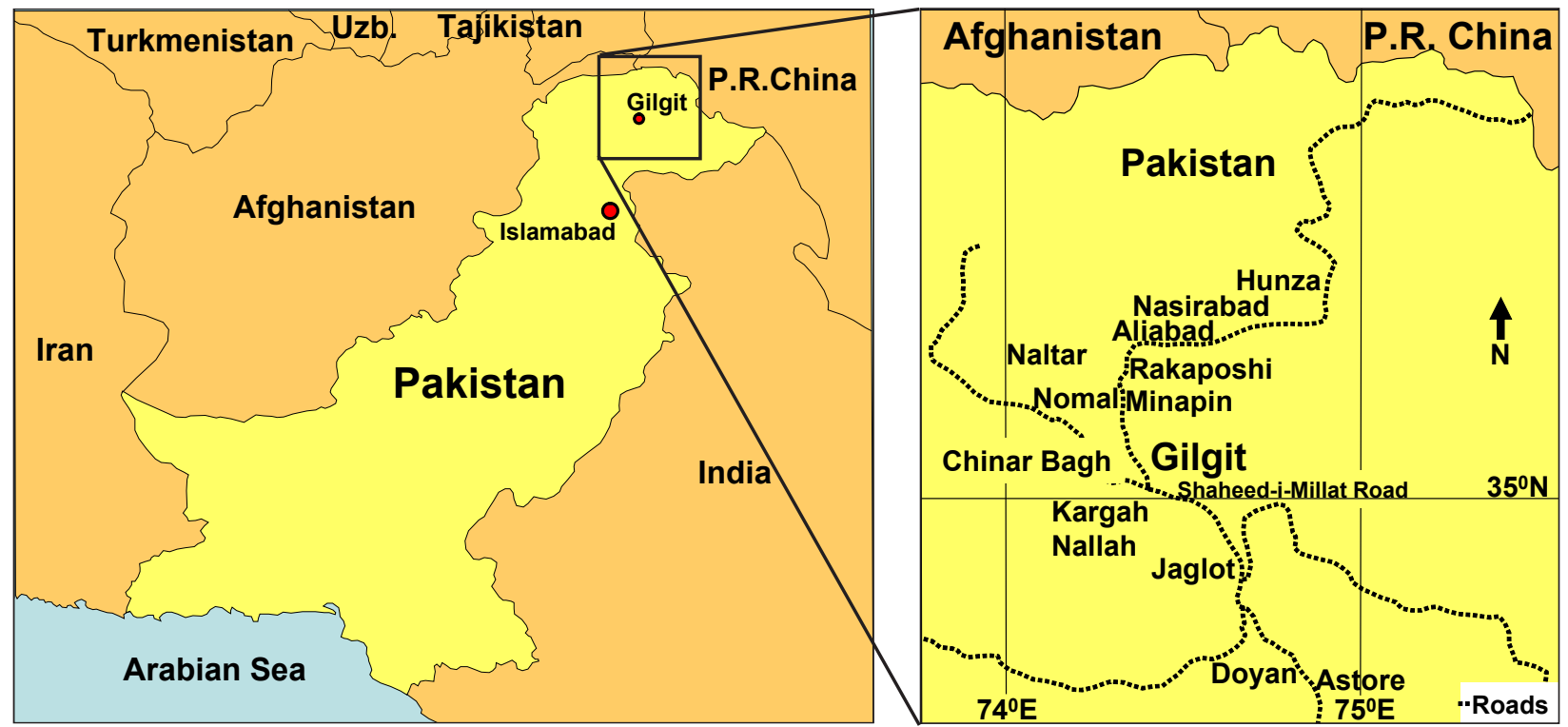

Figure 1. The study site in Gilgit District of northern Pakistan. Information and plants were collected in villages and along roads that converge on Gilgit. 


\section{Qureshi et al. - Ethnobotanical Studies of Medicinal Plants of Gilgit District and Surrounding Areas}

5. Which part of each plant is used for medicinal purposes?

6. Do you collect plants for medicinal purposes?

7. If yes, then:

- When do you collect these plants?

- Do you collect them for your personal use or to sell to pharmaceutical companies?

Plant identification and data recording for traditional uses of these plants in various localities was primarily done by presenting previously collected specimens to older men (belonging to various ethnic groups) and sometimes to older women (if some household use was indicated by male informants). The informants were asked questions, in Urdu (national language of Pakistan) that was understandable in most of the cases. In some cases, paid local assistants were used to ask questions in the informants

local language (mostly Shina). All plants were positively identified by informants with the names and uses connected with specific voucher specimens.

Photographs and voucher specimens were collected or identification in herbarium. Collected plant material has been dried, pressed, preserved (poisoned), accessioned, identified and finally deposited in the herbarium of the Department of Biological Sciences, Quaid-i-Azam University, Islamabad (ISL).

\section{Results}

Table 1 lists the medicinal plant species recorded from the sites studied and uses of plant parts for traditional ailment. 150 voucher specimens of 27 plant species were collect-

Table 1. Medicinal plants of Gilgit district and surrounding areas with information based on interviews with local people using semi-structured and close ended questionnaires.

\begin{tabular}{|c|c|c|}
\hline Taxa (Accession numbers) & Vernacular Names & Plant Parts Used \& Uses \\
\hline \multicolumn{3}{|l|}{ Amaranthaceae } \\
\hline $\begin{array}{l}\text { Amaranthus viridis L. } \\
(123554 ; 123580 ; \\
123578)\end{array}$ & $\begin{array}{l}\text { Chulai (Urdu) } \\
\text { Dhimdo (Shina) }\end{array}$ & $\begin{array}{l}\text { Leaves used as purgative for digestive problems. Have good } \\
\text { emollient properties. }\end{array}$ \\
\hline \multicolumn{3}{|l|}{ Asteraceae } \\
\hline $\begin{array}{l}\text { Artemisia absinthium L. } \\
\text { (123528; 123529; } \\
\text { 129530; 123618; } 123532)\end{array}$ & $\begin{array}{l}\text { Afsantheen (Urdu) } \\
\text { Zoon (Shina) }\end{array}$ & $\begin{array}{l}\text { Whole herb, especially mature round heads used to treat vari- } \\
\text { ous types of fevers, especially malaria. Also used as a anthel- } \\
\text { minthic for children }\end{array}$ \\
\hline $\begin{array}{l}\text { Artemisia maritima L. ex } \\
\text { Hook.f. (123619; } 123620 \text {; } \\
\text { 123653) }\end{array}$ & $\begin{array}{l}\text { Zoon (Urdu) } \\
\text { Rooner (Shina) }\end{array}$ & $\begin{array}{l}\text { Leaves, buds and flowers used as an anthelmintic, especially } \\
\text { for children, for prevention and treatment of gastro-intestinal } \\
\text { ailments in children, and the leaves are applied to boils. }\end{array}$ \\
\hline $\begin{array}{l}\text { Cichorium intybus L. } \\
(123646 ; 123647)\end{array}$ & $\begin{array}{l}\text { Qarali Chicknachi } \\
\text { (Urdu) } \\
\text { Ishkinachi (Shina) }\end{array}$ & $\begin{array}{l}\text { Whole plants are boiled to make a decoction for asthma and } \\
\text { breathing problems related to high altitudes, and also used in } \\
\text { treatment of jaundice and fever. }\end{array}$ \\
\hline $\begin{array}{l}\text { Echinops echinatus Roxb. } \\
(123561 ; 123658 \\
123659)\end{array}$ & $\begin{array}{l}\text { Jachir (Urdu) } \\
\text { Jacheer (Shina) }\end{array}$ & $\begin{array}{l}\text { Whole plants used as a diuretic and as a special fodder for } \\
\text { horses that is believed to treat digestive problems. }\end{array}$ \\
\hline $\begin{array}{l}\text { Taraxacum officinale F.H. } \\
\text { Wigg. } \\
(123541)\end{array}$ & Ishkanachi (Shina) & $\begin{array}{l}\text { Dried powder of leaves and roots is used in a decoction as a } \\
\text { diuretic and as a tonic, and jaundice treatment. The powder } \\
\text { mixed with Hyoscyamus niger } \mathrm{L} \text {. is used for constipation }\end{array}$ \\
\hline \multicolumn{3}{|l|}{ Berberidaceae } \\
\hline $\begin{array}{l}\text { Berberis lycium Royle } \\
\text { (123594; 123595; } \\
\text { 123596) }\end{array}$ & $\begin{array}{l}\text { Ishkeen (Urdu) } \\
\text { Ishkin (Urdu) } \\
\text { Ishkein (Shina) }\end{array}$ & $\begin{array}{l}\text { A decoction of roots is used for treatment of rheumatism, joint } \\
\text { and other pains. Berries and roots are boiled in water and } \\
\text { used to treat diabetes and is highly recommended for bone } \\
\text { injuries and fractures. Sometimes a decoction is applied ex- } \\
\text { ternally on wounds. Flowers and bark also used. }\end{array}$ \\
\hline \multicolumn{3}{|l|}{ Cannabinaceae } \\
\hline $\begin{array}{l}\text { Cannabis sativa L. } \\
(123575 ; 123576 ; \\
123577)\end{array}$ & $\begin{array}{l}\text { Thoonch (Urdu) } \\
\text { Thounch (Shina) }\end{array}$ & $\begin{array}{l}\text { The whole plant is used as a tonic, stomachic and anodyne. } \\
\text { Domestic birds are given its seeds as feed mixed with other } \\
\text { grains to keep them healthy. Roasted seeds mixed with other } \\
\text { dry fruit are used as a special serving to guests in winter sea- } \\
\text { son. The seeds are used raw as a medicine for sore throats. }\end{array}$ \\
\hline
\end{tabular}




\begin{tabular}{|c|c|c|}
\hline Taxa (Accession numbers) & Vernacular Names & Plant Parts Used \& Uses \\
\hline \multicolumn{3}{|l|}{ Cuppressaceae } \\
\hline $\begin{array}{l}\text { Juniperus excelsa M. } \\
\text { Bieb. } \\
(123649 ; 123650 \\
123651 ; 123652) \\
\end{array}$ & Chilli (Shina) & $\begin{array}{l}\text { Berries are used for tuberculosis and diabetes. The berries } \\
\text { are burnt over coal and smoke is spread in all corners of the } \\
\text { house for repelling evils. The paste of berries is applied on } \\
\text { painful joints and swellings. }\end{array}$ \\
\hline \multicolumn{3}{|l|}{ Elaeagnaceae } \\
\hline $\begin{array}{l}\text { Elaeagnus angustifolia L. } \\
\text { (123605; 123606; } \\
\text { 123607) }\end{array}$ & $\begin{array}{l}\text { Ghundair (Urdu) } \\
\text { Ghindawar (Shina) }\end{array}$ & $\begin{array}{l}\text { The whole plant may be used. The fruit is eaten raw or boiled } \\
\text { for sour throat and treatment of cough, flu, colds and various } \\
\text { types of fevers. Gum is used for an asthma treatment. }\end{array}$ \\
\hline $\begin{array}{l}\text { Hippophae rhamnoides L. } \\
\text { (123641; 123642; } \\
\text { 123643; 123644; 123645) }\end{array}$ & Buru (Shina) & $\begin{array}{l}\text { Syrup made from fruit mixed with Morus nigra L. fruit and } \\
\text { sugar is used for cough and bronchial congestion. Paste of } \\
\text { berries is used for skin problems in winter. Locally made jams } \\
\text { and other products have good market value as the medicinal } \\
\text { benefits are known by the general public.. }\end{array}$ \\
\hline \multicolumn{3}{|l|}{ Ephedraceae } \\
\hline $\begin{array}{l}\text { Ephedra gerardiana Wall. } \\
\text { ex C.A. Mey. } \\
\text { (123615) }\end{array}$ & $\begin{array}{l}\text { Sopat (Urdu) } \\
\text { Soopt (Urdu) } \\
\text { Sopt (Shina). }\end{array}$ & $\begin{array}{l}\text { The branches are burned and ash mixed with tobacco to } \\
\text { make naswar (a specific type of snuff). It is used in respira- } \\
\text { tory tract infections especially in the Astore area. The whole } \\
\text { plant is boiled in water and the paste applied on bone frac- } \\
\text { tures that are not healing properly. This helps to "de-heal" in- } \\
\text { appropriately healed bones. An interviewee (old lady) indicat- } \\
\text { ed that she was using crushed material boiled and mixed with } \\
\text { common salt applied to relieve painful joints. }\end{array}$ \\
\hline \multicolumn{3}{|l|}{ Fabaceae } \\
\hline $\begin{array}{l}\text { Trifolium pratense L. } \\
\text { (123534) }\end{array}$ & $\begin{array}{l}\text { Trepatra (Urdu) } \\
\text { Chita-batta (Shina) }\end{array}$ & $\begin{array}{l}\text { Powder of dried flowers is given by herbalists for whooping } \\
\text { cough as an expectorant and antiseptic. It is also given in } \\
\text { bronchitis and asthma. }\end{array}$ \\
\hline \multicolumn{3}{|l|}{ Lamiaceae } \\
\hline $\begin{array}{l}\text { Mentha longifolia }(\mathrm{L} .) \\
\text { Huds. } \\
(123484 ; 123490 ; \\
123547 ; 123548 ; 123549)\end{array}$ & $\begin{array}{l}\text { Phileel (Urdu) } \\
\text { Fileel (Shina). }\end{array}$ & $\begin{array}{l}\text { Tea from leaves is used to treat migraines, headaches, colds, } \\
\text { nasal catarrh, fever, indigestion and profuse mucus dis- } \\
\text { charge. The leaves and flowers heads are used as a carmina- } \\
\text { tive and stomachic, astringent and antirheumatic and to treat } \\
\text { whooping cough, asthma and respiratory inflammation. }\end{array}$ \\
\hline Thymus serpyllum L. & Tumuro (Shina). & $\begin{array}{l}\text { Dried leaves are used in treatment of whooping cough, asth- } \\
\text { ma and respiratory inflammation. Hakeem (local herbalists) } \\
\text { distill volatile oil from the leaves to use as a deodorant and } \\
\text { strong antiseptic. The whole plant is used for stomach trouble } \\
\text { and fever. }\end{array}$ \\
\hline \multicolumn{3}{|l|}{ Plantaginaceae } \\
\hline $\begin{array}{l}\text { Plantago major L. } \\
\text { (123613; 123614) }\end{array}$ & $\begin{array}{l}\text { Jangli palak (Urdu) } \\
\text { Isp-ghoal (Urdu) } \\
\text { Shiltive (Shina) }\end{array}$ & $\begin{array}{l}\text { Root powder is considered to be a very effective pain killer for } \\
\text { toothache and gum problems, chronic dysentery, diarrhea and } \\
\text { constipation. Seeds and leaves are also used. }\end{array}$ \\
\hline \multicolumn{3}{|l|}{ Polygonaceae } \\
\hline $\begin{array}{l}\text { Polygonum hydropiper L. } \\
(123485 ; 123486)\end{array}$ & $\begin{array}{l}\text { Not available. } \\
\text { Water pepper }\end{array}$ & $\begin{array}{l}\text { Leaves are used as a diuretic, to lower blood pressure, and } \\
\text { as temporary relief in heart diseases such as angina. }\end{array}$ \\
\hline $\begin{array}{l}\text { Rumex hastatus D. Don } \\
(123515 ; 123516 ; \\
\text { 123517; } 123518 ; 123519 ; \\
123520)\end{array}$ & Churki (Shina) & $\begin{array}{l}\text { Leaves are used for their sour taste and carminative stomach- } \\
\text { ic, flavoring and purgative characters. The entire plant, espe- } \\
\text { cially the roots may be used. }\end{array}$ \\
\hline $\begin{array}{l}\text { Rumex nepalensis } \\
\text { Spreng. (123491) }\end{array}$ & Churkeen (Shina). & The roots are used as a strong purgative. \\
\hline
\end{tabular}



and Surrounding Areas

\begin{tabular}{|c|c|c|}
\hline Taxa (Accession numbers) & Vernacular Names & Plant Parts Used \& Uses \\
\hline \multicolumn{3}{|l|}{ Poaceae } \\
\hline $\begin{array}{l}\text { Saccharum bengalensis } \\
\text { Retz. } \\
(123621 ; 123622)\end{array}$ & $\begin{array}{l}\text { Chaar (Urdu) } \\
\text { Phoroo (Shina) }\end{array}$ & $\begin{array}{l}\text { Roots are locally used as a diuretic and demulcent by old } \\
\text { people. The stem is as a refrigerant and aphrodisiac agent. }\end{array}$ \\
\hline \multicolumn{3}{|l|}{ Ranunculaceae } \\
\hline $\begin{array}{l}\text { Clematis baltistanica R.A. } \\
\text { Qureshi \& M.N. Chaudhri } \\
\text { (123521; 123522; } \\
\text { 123523; 123524) }\end{array}$ & $\begin{array}{l}\text { Morgush (Urdu) } \\
\text { Margush (Shina) }\end{array}$ & $\begin{array}{l}\text { Leaves and flowers are ground into a paste and used as } \\
\text { a skin ointment for treatment of pimples, boils, bumps and } \\
\text { burns. }\end{array}$ \\
\hline $\begin{array}{l}\text { Ranunculus trichophyl- } \\
\text { lus Chaix ex Vill. (123538; } \\
\text { 123539; 123540) }\end{array}$ & Not available & $\begin{array}{l}\text { The whole plant is used for treatment of fever and rheumatic } \\
\text { pain. }\end{array}$ \\
\hline \multicolumn{3}{|l|}{ Salicaceae } \\
\hline Salix alba L. (123555) & Mori Bayao (Shina) & $\begin{array}{l}\text { Powdered bark is mixed with other herbs to be used as an } \\
\text { anti-periodic, tonic and astringent. The leaves and bark are } \\
\text { used to treat diarrhea and dysentery. }\end{array}$ \\
\hline $\begin{array}{l}\text { Salix tetrasperma Roxb. } \\
(123508 ; 123509 \\
123648)\end{array}$ & Byao (Shina) & $\begin{array}{l}\text { The bark is used as a febrifuge. Leaves are placed in bedding } \\
\text { of the patient and all over the body, in armpits and ear canals } \\
\text { as part of the process of lowering body temperature. Sleeping } \\
\text { in such a situation is believed to treat fever quickly. }\end{array}$ \\
\hline \multicolumn{3}{|l|}{ Scrophulariaceae } \\
\hline $\begin{array}{l}\text { Veronica anagallis-aquat- } \\
\text { ica } \mathrm{L} . \\
(123582)\end{array}$ & & $\begin{array}{l}\text { Whole plant is believed to treat scurvy, and is used as a di- } \\
\text { uretic and sometimes to treat hemorrhoids. An ointment made } \\
\text { of stems and leaves is applied on burns, ulcers and wounds. }\end{array}$ \\
\hline \multicolumn{3}{|l|}{ Solanaceae } \\
\hline $\begin{array}{l}\text { Datura stramonium L. } \\
\text { (123500; 123501; } \\
\text { 123502; 123551) }\end{array}$ & Daturo (Shina) & $\begin{array}{l}\text { Flower juice is used for earaches. Fruit juice is used to treat } \\
\text { dandruff and hair loss. Seeds are burned then placed on a } \\
\text { toothache or are used as an anti-spasmodic and narcotic. A } \\
\text { paste of dried leaves is applied to boils and sores. }\end{array}$ \\
\hline $\begin{array}{l}\text { Solanum nigrum L. } \\
\text { (123672; 123673) }\end{array}$ & $\begin{array}{l}\text { Mako (Urdu) } \\
\text { Gabeeli (Shina) }\end{array}$ & $\begin{array}{l}\text { Leaves are mixed with fodder to treat digestive problems of } \\
\text { goats and sheep. Berries are consumed or prepared as a de- } \\
\text { coction to treat jaundice. }\end{array}$ \\
\hline
\end{tabular}

ed from the study areas. Figure 2 illustrates the extent of knowledge by gender and age class.

\section{Discussion}

\section{Knowledge distribution by age and gender}

The results show that gender and age class differ in their traditional knowledge with regard to medicinal plants reported. Males above 50 year of age had more traditional knowledge about medicinal plants and their uses than females. This may be attributed to their involvement in trade related activities. In most of the cases the older people were noted as being better informants and the vivid reason for this may be their personal experience of using these plants since old times (especially before the construction of Karakoram Highway in the region and the start of modern development activities).
Respondents under 50 years of age were less aware of the potential of medicinal plants than their older counterparts who have gathered knowledge from the point of view of their traditional health care and their day to day practices. This difference in the perception of the two age classes will likely result in knowledge loss over time.

We learned through the survey that local people are still dependent on plant resources for treatment of various ailments, but this dependence is decreasing. This is likely due to multiple reasons. One such reason is lack of belief of the young generation in the traditional medicine systems and increasing use of allopathic medicines due to their availability and efficacy. Another reason likely associated with the decline of folk medicinal use of plants is large scale collection/ harvest by drug manufacturers especially in areas near settlements and pastures, leaving behind very little for access by local communities. 


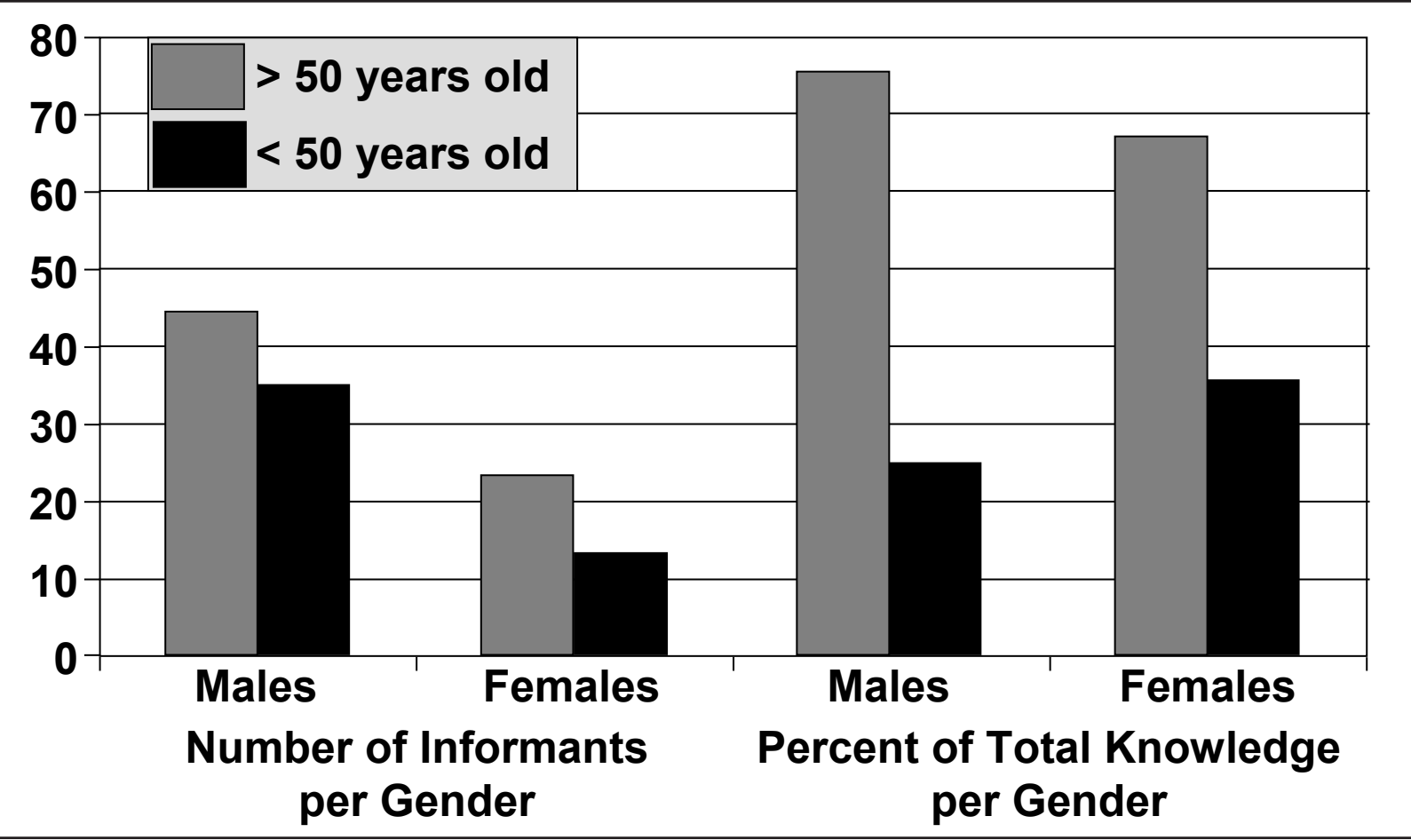

Figure 2. Comparison of number of informants by age and percent of medicinal plant knowledge held by men or women of different ages in Gigil District and surrounding areas of Pakistan.

\section{Uses of medicinal plants}

Many people reported experiencing improper healing of fractured bones. The only way in medical science to treat such cases is through surgery with subsequent plastering for longer time periods. This is a hectic experience for patients. In this study, it was found that people use Ephedra gerardiana branch ash paste (in water or oil base) and in some cases a warm decoction or extract of other parts of the plant externally applied on the area of the bone fracture. This was said to heal the improperly healing fractured bone within a week. A decoction prepared from Berberis lycium was also recommended by the elderly respondents of this survey for the speedy healing of bone fractures. The decoction is recommended to be used with boiled and sweetened milk administered orally and for a certain period of time (a week to a month), depending on the age of the patient. Another type of concentrated decoction is prepared for treating bone fractures by adding a small quantity of selajit (a local mineral seepage from steep rocks having mineral phosphorus). Only one teaspoon with one glass of milk is taken twice a day.

In our study area Artemisia absinthium was found to be the most frequently used medicinal plant followed by Artemisia maritima. Both are reported for treatment of gastrointestinal infections and helminthic problems in children. Uses of various Artemisia species as tonics and anthelmintics has also been reported by Rasool (1998). Artemisia species are also used to treat various types of fevers especially from malaria. This is interesting in light of recent reports (Shinwari et al. 2002) indicating that Quinine resistant malaria may be effectively treated by Artemisnine from Artemisia annua L.

Many plant species are used as purgatives and stomachics including Amaranthus viridis, Mentha longifolia, Thymus serpyllum and Rumex hastatus. Similar uses for these species were verified (with the exception of Rumex hastatus) from the work Rasool (1998) and Shinwari et al. (2002). Kazmi and Siddiqui (1953) reported, in an early ethnobotanical survey of Astore, that some medicinal species are used in bronchial and lung diseases e.g. Hippophae rhamnoides and Elaeagnus angustifolia. In addition to these species we also found that Cichorium intybus, Trifolium pratense and Thymus serpyllum are used in asthma, whooping cough, lung complains and breathing problems related to higher altitude.

This study has identified at least three species: Ephedra gerardiana, Thymus serpyllum and Plantago major that we feel should be locally cultivated because they have good adoptability to local climates and have high market values. These plants can be cultivated with little input for benefits to the community. Similar recommendations come from the work of Shinwari et al. (2000b) who suggested that plants such as Nigella sativa L. (Black cumin), Foeniculum vulgare Mill. (fennel), Plantago ovata Forssk. (flea seed) and Mentha arvensis L. (mint) are suited to the ecological conditions of Pakistan and could be adopted as minor cash crops. It was found that some shrubs of medicinal value such as Hippophae rhamnoides and Ber- 


\section{Qureshi et al. - Ethnobotanical Studies of Medicinal Plants of Gilgit District and Surrounding Areas}

beris lycium are difficult to maintain. However, because of their potential uses, these are recommended for sustainable harvest, with use as firewood and for fencing being avoided. This can only be done by proper training and involvement of local communities in conservation practices Aumeeruddy (1996).

\section{Conservation issues}

We observed that medicinal plants are indiscriminately collected from wild habitats for domestic and commercial uses without any strategies reported to conserve them. This lack of effort to sustain resources may result in their depletion from natural habitats. There is a great need to create awareness among the indigenous communities about endangering medicinal plants if over exploited to meet market demand.

Our attempts to collect local medicinal plants support the findings of Shinwari et al. (2002) that some medicinal plant species known to grow in Northern areas of Pakistan, e.g. Ferula narhex Boiss., Podophyllum hexandrum Royle, and Saussurea costus (Falc.) Lipsch., are very rare and not growing in approachable tracts. However, Tamarix gallica L., reported to be endangered by these workers, was found to be abundant in our study areas. Shinwari et al. (2002) also found that overall rich biodiversity directly correlated with the number of medicinal species found in an area. Their observations are consistent with those of Salick et al. (1999), who established a direct relationship between biodiversity and useful plants among the Dusun of Mt. Kinabalu. In our study area, Naltar and Astore were particularly rich areas in diversity and hence yielded many medicinally important species. Similarly Shinwari et al. (2000a) noted that as overall diversity increases so does medicinal plant species, reporting 345 medicinally used species from the biologically diverse Swat. Our results of only 27 species reported from an estimated flora of 3,000 species and at least 124 known medicinal plants indicates either an extreme loss of knowledge or accessible plant diversity in the study area and/or the need for more research with differing methods.

\section{Conclusion and Recommendations}

We think that the present status of the economically and medicinally important plants of the study area needs to be determined in order to develop plans for their protection. Improved awareness of conservation issues is needed. Proper documentation of indigenous knowledge about the plants could be supportive in achievement of objectives.

The vast area, big pastures and suitable climatic conditions make it possible for a large number of threatened medicinal plants and other useful species to grow in the study area. Local cultivation of medicinal plants and other economic species can play an important role in eco- nomic development of the area, in particular and Pakistan's economy in general, by earning valuable foreign exchange and meeting domestic requirements. As every year a considerable amount of foreign exchange is spent for the import of drugs and other products, sustainable utilization of indigenous drug resources in local pharmaceutical and herbal industries will increase the importance of the plant resources of these areas. Utilization of indigenous drug resources will increase the importance of the local industry on one hand and minimize the expenditure incurred on the purchase of foreign drugs on the other. It can also provide direct and indirect employment to a large number of people from trained collectors to local herb sellers and also support a good number of herb-based industries. In view of the present study of medicinal plants (as well as other economic uses of plants), research and conservation efforts should be focused on these resources of the area. It is proposed to establish a comprehensive research project to improve the production of medicinal and other useful plants in this area. For sustainable and long term conservation of natural resources of the area, there is a need to actively involve the quiescence of local people in evaluation, planning, implementation and monitoring processes as they are the best judges of the area.

\section{Literature Cited}

Aumeeruddy, Y. 1996. Ethnobotany, Linkages with conservation and development. Pp. 152-157 in Proceedings of First Training Workshop on Ethnobotany and its Application to Conservation. NARC, Islamabad.

Bisht, A.K., R.S. Bhattia, R.S. Rawal \& D. Uppeandra. (2006). Prioritization and conservation of Himalayan medicinal plants: Angelica glauca Edgew. as a case study. Ethnobotany Research and Applications 4:11-23.

Delcourt, P.A., H.R. Delcourt, P.A. Cridlebaugh \& J. Chapman. 1986. Holocene ethnobotanical and paleoecological record and human impact of vegetation in the little Tennessee River Valley, USA. Quaternary Research 25:330349.

Dhar, U., R.S. Rawal \& J. Upreti. 2000. Setting priorities for conservation of medicinal plants - a case study in Indian Himalaya. Biological Conservation 95:57-65.

Hussain, F. \& A. Khaliq. 1996. Ethnobotanical studies on some plants of Dabargai Hills, Swat. Pp. 207-215 in Proceedings of First Training Workshop on Ethnobotany and its Application to Conservation. NARC, Islamabad.

Kamboj, V.P. 2000. Herbal medicine. Current Science 95:57-65. 
Kazmi, M.A. \& I.A. Siddiqui.1953. Medicinal plants of Astore and upper Gurraiz valley. Pakistan Journal of Plant Sciences 1:217-223.

Pei, S. 1992. Mountain Culture and Forest Resource Management of Himalaya. Pp. 114-120 in Himalayan Ecosystem. Edited by D.W. Tewari. Intel Book Distribution, Dehra Dun, India.

Qureshi, R.A. \& M.A. Ghufran. 2005. Medicinal value of some important roses and allied species of Northern Areas of Pakistan. Pp. 24-29 in Pakistan Rose Annual. Edited by M. Hashmi. Pictorial Printers (pvt.) Ltd. Islamabad.

Rasool, G. 1998. Medicinal Plants of the Northern Areas of Pakistan: Saving the plants that save us. Gilgit, Pakistan.

Salick, J., A. Biun, G. Martin, L. Apin \& R. Beaman. 1999. Whence useful plants? A direct relationship between biodiversity and useful plants among the Dusun of Mt. Kinabalu. Biodiversity and Conservation 8:797-818.

Shinwari, Z.K., S.S. Gilani, M. Kohjoma \& T. Nakaike 2000a. Status of Medicinal Plants in Pakistani HinduKush Himalayas. Pp. 235-242 in Proceedings of NepalJapan Joint Symposium on Conservation of Natural Medicinal Resources and their Utilization. Kathmandu, Nepal, Nov. 5-11, 2000. Edited by T. Watanabe, A. Takano, M.S. Bistan \& H.K. Saiju. Society for the Conservtion and Development of Himalayan Medicinal Resources, Tokyo, Japan.

Shinwari, Z.K., T. Watanabe \& Y. Yousaf. 2000b. Medicinal Plants of Pakistan: An overview. Pp. 279-285 in Proceedings of Nepal-Japan Joint Symposium on Conservation of Natural Medicinal Resources and their Utilization. Kathmandu Nepal, Nov. 5-11, 2000. Edited by T. Watanabe, A. Takano, M.S. Bistan \& H.K. Saiju. Society for the Conservtion and Development of Himalayan Medicinal Resources, Tokyo, Japan.

Shinwari, Z.K. \& S.S. Gilani. 2003. Sustainable harvest of medicinal plants at Bulashbar Nullah, Astore (Northern Pakistan). Journal of Ethnopharmacology 84:289-298.

Shinwari, Z.K., S.S. Gilani \& M. Akhlas. 2002. Sustainable Harvest of Medicinal Plants at Bar and Shinaki Valleys, Gilgit (Northern Pakistan). Consultancy Report, World Wildlife Fund-Pakistan, Gilgit, Pakistan.

Stewart, R.R. 1972. An Annotated Catalogue of the Vascular Plants of West Pakistan \& Kashmir. Pp. 663-668 in Flora of West Pakistan. edited by E. Nasir \& S. I. Ali. The National Herbarium, Islamabad.
Tandon, V. 1996. CAMP workshop-plants under threat new list forged. Medicinal Plants Conservation Newsletter 2:12-13.

UNDP/IUCN 1999. Report on Biodiversity of Northern Areas, Pakistan. (Unpublished). 